にして行きたい.

13. X線写真による撮影システムの一元評価の試み

国立循環器病センタ一放射線診療部

○岡千津子・若松孝司・坂下善治 巣組一男

[目的]

撮影系は写真構成の為のシステムであり，乙れが一定 レベル以上であれば，出てくる写真も安定しているとい える. との指標を得るのにエントロピー法を用いてみた. [方法]

胸部写真 (男, 女, Phantom 各100枚ずつ) 測定点10 点の濃度をエントロピー法で処理し伝達効率をその指標 とする.

[結果, 考察]

当センターの写真では伝達効率約 $40 \%$ であった。 これ 以上の效率を持つシステムから出された写真ならば，診 断に充分椋え得ると思われる. 今後他施設との比較を行 ってゆきたい.

14. The Determination of Xray Wavelength Distributions from Absorption Data

一いわゆる Greening 法の再検討——

滋賀医科大学病院放射線部

○森岡康範・雄川港行・陶山純夫

Greening の方法を今回は検討した，今後他の測定法 で，实際ゆ spectrum を確認する必要があるが，幾何学 的条件を満足すれば，充分実用に供せると思われた，又 とれらの結果より, 付加 filter 及び被写体による Spectral Hardening 現象はかなり大きいととが確認された。 被写体加らの散乱線 spectrum の測定は，他の測定法を 手考慮して今後行っていくべきと考える.

\section{5. 散乱因子の画質に及ぼす影響について}

京都第一日赤病院放射線科

○荒木信義・南郷武好・木下伸治

田辺一弘・平川益三・西村信男

[目的]

散乱因子が画質にどのように影響しているのか矩形波 チャートを用いレスポンスを測定することで定量的に評 価した。

[結果]

(1)管電圧，ファントム厚を変えながらレスポンスを比 較したが，いずれの場合も受光部を入れるてとにより80

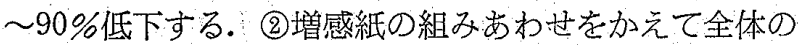
系のレスポンスを比較する之，被写体が厚くなる程感度 の低い増感紙の撮影系のレスポンスがより低下した。 と
れは線量がふえることからくる散乱線によるボケの影響 と思われる. (3)現在前面增感紙保持アクリルル $\mathrm{mm}$ を, より透過性の良いトレカ $2 \mathrm{~mm}$ 亿変更するととを検討中 であり，どれだけ画質が上がるかひきつづき検討してい きたり.

\section{6. 被写体散乱線による画像評価の問題点}

星ケ丘擪生年金病院放射線部

○米岡敏雄・長畑 弘・木村正明

岩家明子・木村典子

\section{[目的〕}

散乱線を含む評価法には，土井等の報告にもあるMTF 評洒法がある，それは，散乱線含有率から近似計算によ り求める方法である。し办し，散乱線含有率を求める過 程は複雑で難しい。とてで，散乱線含有率を用いず矩形 波チャートを使用し，コントラスト法で散乱線を含む MTF を求め, 従来の方法と比較検討を行った。

〔結果】

散乱線含有率より求めた MTF と比較すると, チャ゙ー トとフィルム間距離が $0 \mathrm{~cm} の \mathrm{MTF}$ と同一傾向を示し た、同じ厚さのファントムの中においては，掋大率の補 正を行ってあ, チャートがフィルムに密着したものが最 あ良く、フィルムから離れる程 MTF は低下した。 以上， 散乱線による画質の傾向を簡単に得ることができた。

\section{7. 螢光増感による高感度電子 $X$ 線写真の画質特性とそ の有用性}

\section{阪大微研病院放射線科}

○山崎和江 · 山田淳子 · 寺田 先

從来の電子X線写真は，低感度のため十分に活用普及 がなされていない。今回，螢光増感による感度向上を計 うた KIP 方式についてその画質特性及び診断的有用性 について報告した。

感度については, $\mathrm{ZnS}$ 紊螢光体の使用により銀塩写真 の約 $1 / 3$ 倍, ゼロラジオグラフィーの約1.5倍にとどまっ たが，従来，稀土類系營光体を使用するてとにより，よ り一層の感度向上が期待できる．また臨床的には，乳腺： 疾患をはじめ四肢骨，頭頸骨において診断性の高い画像 が得られ，今後更に診断領域の拡大が望めるものと思わ れる.

18. 各種フィルムの臨床評価一第 2 報一

ーコンデンサー式回診装置を用いて一

大阪大学医学部付属病院中央放射線部

○大原由起子 ·坂手敏昭 $\cdot$ 前田大助

山本清澄・高橋秀彰・坂本真一

私達が日常行っているポータブル型撮影装置を用いた 